\title{
Learner Agency Through Language Portfolios
}

\section{Motoko Teraoka \\ Kindai University}

\section{Reference Data:}

Teraoka, M. (2020). Learner agency through language portfolios. In P. Clements, A. Krause, \& R. Gentry (Eds.), Teacher efficacy, learner agency. Tokyo: JALT.

https://doi.org/10.37546/JALTPCP2019-41

Whether or not language portfolios (LPS) can promote learner agency is examined in this paper in relation to Bandura's (2001) core features of human agency: intentionality, forethought, selfreactiveness, and self-reflectiveness. In the 2018 fall semester, LPs were implemented in 4 EFL courses with 82 students at a Japanese university. Self-assessment checklists, class observations, and LP inspections were used to explore their effects. It was concluded that LPs may help promote human agency among students, in particular intentionality and self-reactiveness. However, it can be difficult to determine whether or not forethought and self-reflectiveness are fostered through LPs. Teachers' timely intervention in students' learning in the classroom, depending on the students' English proficiency levels, learning purposes, and attitudes, is vital for successful implementation and optimization of LPs, as are teachers' continued efforts to improve the efficacy and efficiency of LPs to promote learner agency.

本論では、ランドージ・ポートフォリオ (LP) が学習者の主体性を引き出す可能性があるかを調査した。主体性と は、Bandura (2001) が提唱する、人の営みの核となる特性、すなわち、意四性・事前の計画·自己反応性·自己内省である。 LP

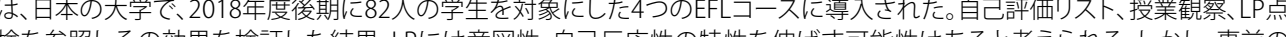

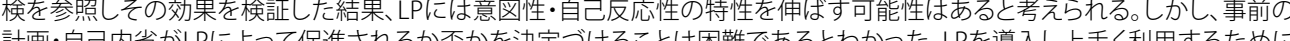

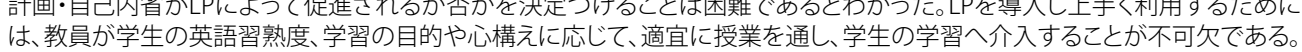

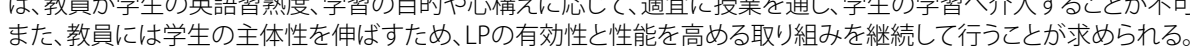

gency empowers students throughout their learning processes and gives them

self-confidence in engaging in each step towards their learning goals. Moreover, not only does this empowerment influence students' learning but promoting learner agency also benefits students' entire lives because "Agency embodies the empowerments, belief systems, self-regulatory capabilities and distributed structures and functions through which personal influence is exercised" (Bandura, 2001, p.1). Learner agency in this study focused mainly on Bandura's (2001, p. 6) four core features of human agency: intentionality, forethought, self-reactiveness, and self-reflectiveness.

\section{Bandura's Core Features of Human Agency}

Intentionality is "a proactive commitment to bring about future actions"; forethought is "the ability to bring anticipated outcomes to bear on current activities" (p. 7); selfreactiveness is "the ability to give shape to appropriate courses of action and to motivate or regulate their execution" (p. 8); self-reflectiveness is "the metacognitive capability to reflect upon oneself and the adequacy of one's thoughts and actions" (p. 10). Before taking any action, people first have an intention to carry out that action, consider appropriate methods or procedures, and then make plans to accomplish the intention. They try out a method and improve or completely change it to produce expected results. After that, people observe actual outcomes and reflect on the whole process they went through. Importantly, this may also be applicable to language learners. Starting with goal-setting, language learners make plans to achieve their goals, motivate or regulate their learning paths, and then reflect on their learning progress and processes. Successful language learners will thus exert human agency to attain their learning goals.

One way for individual students to track their learning progress and processes is to employ language portfolios (LPs) in the EFL classroom. The European Language Portfolio (ELP) is one of the most highly regarded examples of LPs and many educators attest to its effectiveness for enhancing learner autonomy in areas such as promoting goal-setting, 
self-reflection, self-assessment, and self-directed learning (e.g., Esteve, Trenchs, Pujolà, Arumi, \& Birello, 2012; Kohonen, 2012; Little, 2012).

\section{The European Language Portfolio}

The ELP was first launched as a component of the Common European Framework of Reference (CEFR) in 2001. It is a personal document and information tool that enables its owner to present their language proficiency and intercultural experience throughout Europe. The ELP comprises three key components: Language Passport, Language Biography, and Dossier (Kühn \& Cavana, 2012). A description of the three key components is provided by Martyniuk (2012). The Language Passport serves as a certificate of a learner's language competences that can be described in accordance with common criteria accepted throughout Europe, and the learner updates it regularly. The Language Biography describes a learner's own experiences in each language, focusing on what they can do in the target language. In this component, goal-setting, and selfassessment using "I can" checklists are of vital importance in facilitating the learner's involvement in their own learning. The Dossier is a collection of examples of a learner's personal work to illustrate their language competences (for more details about the three components see Council of Europe, 2019).

\section{Previous Studies on Language Portfolios}

Numerous advantageous applications of LPs have been reported. Esteve et al. (2012) defined the ELP as a mediation tool because it allows teachers to mediate in students' learning and to help develop students' awareness of their level of competence, the degree to which they are advancing towards their learning goals and the most appropriate resources and strategies for their learning. Reeve, Ryan, Deci, and Jang (2008) discussed how teacher-initiated external events, such as competence-affirmative feedback, preserve learner autonomy and encourage students' intrinsic motivation. A previous study by Teraoka (2015) demonstrated that LPs became a tangible and personal learning tool for students as a resource for quiz review and their reflection on class content. LPs were also found to serve as a communication tool between teacher and student and allowed the whole class to share individual learning processes in a supportive learning environment (Teraoka, 2016). Exploring the assessment potential of LPs, Esteve et al. treated the adapted ELP in their ESL tertiary education contexts as part of formative assessment, granting $40 \%$ out of the $100 \%$ grade with the ratio of summative assessment of examination results reduced to promote learner autonomy and make students more responsible for their learning.
However, the concept of learner autonomy in the ELP that is evident in plurilingualism and interculturality lacks direct relevance in Japan's EFL contexts (Horiguchi, Harada, Imoto, \& Atobe, 2010). Therefore, LPs have to be adapted for such learning and teaching contexts to help students to promote learner agency. That is why in this study, I explored the possibility of whether LPs created for and with specific EFL classes can promote learner agency of Japanese university students.

\section{Study Purpose}

The theme of the JALT2019 International Conference, "Teacher Efficacy, Learner Agency," provided an opportunity to take a different perspective and consider whether LPs can promote learner agency, in particular in relation to Bandura's core features of human agency. In order to explore this, I decided to examine LPs that had already been implemented in four EFL courses at the beginning of the 2018 fall semester.

\section{Implementing LPs in Class}

\section{Participants}

The use of LPs was incorporated into university EFL classes involving 82 students from four different courses. The contents of the four courses and participants' backgrounds are summarized in Table 1.

\section{Table 1. Description of Four EFL Courses}

\begin{tabular}{|c|c|c|c|c|c|}
\hline Course & Name & Type & Focus & Number of Ss & Level of Ss \\
\hline A & English 2B & Required & Basic 4 skills & 32 & $\begin{array}{c}\text { TOEIC } \\
250-300\end{array}$ \\
\hline B & Writing B & Elective & $\begin{array}{l}\text { SVOC patterns } \\
\text { Writing }\end{array}$ & 23 & $\begin{array}{c}\text { TOEIC } \\
350-450\end{array}$ \\
\hline C & TOEIC B & Elective & $\begin{array}{l}\text { TOEIC scores of } 500 \\
\text { or above }\end{array}$ & 18 & $\begin{array}{c}\text { TOEIC } \\
350-450\end{array}$ \\
\hline $\mathrm{D}$ & $\begin{array}{l}\text { Advanced } \\
\text { TOEIC B }\end{array}$ & Elective & $\begin{array}{l}\text { TOEIC scores of } 700 \\
\text { or above }\end{array}$ & 9 & $\begin{array}{c}\text { TOEIC } \\
550-650\end{array}$ \\
\hline
\end{tabular}

Note. Ss $=$ students. 
The classes comprised 54 male students and 28 female students. Among them, only six were 3rd-year or 4th-year students, and the rest were all 2nd-year students. During the 2018 fall semester, I met with the students once a week for 90 minutes over a 15-week period. Informed consent was obtained from all participants.

\section{Procedure}

Course-Oriented Materials

When implementing LPs, I focused particularly on the Dossier, as this element is often considered "the backbone" of the ELP (Esteve et al., 2012, p. 83). Students in each of the four EFL courses created their own LPs starting from the 2018 fall semester. I produced five main course-oriented documents for each class, focusing on five areas that required learner autonomy: planning, preparation, recording, reflection, and assessment, as shown in Table 2. To those areas, particular documents were allotted.

Table 2. Autonomy Aspects of Five Class Documents

\begin{tabular}{ll}
\hline Autonomy aspect & Course-oriented document \\
\hline Planning & $\begin{array}{l}\text { Syllabus (course design, requirements, grading criteria, and } \\
\text { attendance policy stipulated) }\end{array}$ \\
Preparation & Pre-class document: vocabulary list or warm-up question sheet \\
Recording & In-class document: daily worksheet \\
Reflection & Post-class document: review quiz \\
Assessment & Self-assessment checklists 1 and 2 \\
\hline
\end{tabular}

Students were required to complete these documents at home and in class and compile them in an A4 folder with 20 pockets. This folder and its contents constituted the LP, which accounted for $15 \%$ of the entire grading ratio as part of formative assessment. I inspected their LPs twice after the students had completed the two selfassessment checklists.

\section{Self-Assessment Checklists}

I created two self-assessment checklists that were designed for students to assess their own learning progress and processes using a 5-point Likert scale of 1 (not at all) to 5 (very much). Self-assessment Checklist 1 and Self-assessment Checklist 2 were given in class in the middle and at the end of the semester respectively. The items on Checklist 1 varied from course to course. For Courses A and B, the check items focused on students' understanding of class content, whereas for Courses C and D, the check items were related to students' abilities to perform tasks by using TOEIC listening and reading strategies. In addition, Course A students were asked a question related to classroom behavior, and those in Courses $C$ and D were asked whether they had self-studied for the TOEIC test outside the class.

Other aspects that all the students self-assessed included revisiting their LPs, class preparation, class review, and class participation. Furthermore, they were asked whether they had organized class documents in their LPs. To self-assess their efforts to improve the efficacy of their LPs, the students were also asked whether they had added to the worksheets extra information gained in class that was useful for their learning. In addition, they were encouraged to write their goals for the latter half of the semester and how to achieve those goals. Checklist 1 was collected in the middle of the semester and returned to each student with my written feedback.

The feedback varied, and I tried to give specific or explicit advice to help students to reach their goals. For instance, when asked how to achieve learning goals for the latter half of the semester, a student wrote, "I will study grammar and improve my vocabulary with a reference book little by little every day." I underlined "little by little every day" with red ink and commented, "Try to start with 15 minutes just before going to bed." To the same question, another student responded, "I want to improve the review quiz score by studying in a more efficient way." My comments were "The content of review quizzes is getting more difficult than that in the first half of the semester. First, reflect on your current way, as well as time allocation. You may need to spend more time preparing for review quizzes." Those comments were made in Japanese, but for some students in Course D, the feedback was written in English.

Checklist 2 was mainly designed to observe students' learner agency (see Appendix) The same 12 check items based on Bandura's core features of human agency were given to all the students. I interpreted intentionality and forethought as thought; selfreactiveness as action; and self-reflectiveness as reflection. Check items for thought had the students self-check their understanding of the syllabus content and selfask whether they had made plans for class preparation and review, referring to the syllabus. With check items for action, the students self-assessed worksheet completion, worksheet organization, their LP efficacy, and revisitations of their LPs. Regarding reflection, the students self-reflected on class participation and the benefit of their LPs 
Teraoka: Learner Agency Through Language Portfolios

for their ongoing learning. They also reflected on whether the creation of their LPs had given a sense of achievement, had become a good reference to their learning, and had encouraged self-reflection on their learning. Lastly, the students rated their LPs on a 5 -point Likert scale of 1 (poor) to 5 (excellent).

In addition to those 12 check items, the students commented on the reasons for their LP ratings and how their LPs had actually contributed to their learning. Also, to assess students' self-reactiveness more precisely, I asked them to comment on what they had done to improve their learning after completing Checklist 1 . As the final self-assessment commentary, they self-assessed whether they achieved the goals that they had set midsemester and were asked to justify their judgment (see Appendix).

When using self-assessment checklists in classes, one of the main issues to consider is that the validity of response data can be difficult to establish. Sato (2010) suggested that a lack of opportunities for students to self-assess their learning makes it difficult for them to conduct self-assessment accurately, partially resulting in poor reliability in self-assessment. Therefore, Checklist 1 served as an introductory tool for the students to become accustomed to self-assessment. Another issue with students' self-assessment is that it is difficult to elicit their honest opinions and views about themselves, and issues of power relations between teacher and student may arise. Students may attempt to impress or please teachers by overrating their abilities or performances, or deliberately making comments on their learning that may be matched with teachers' expectations. To reduce such concerns, I clearly informed the students both verbally and in writing that any outcomes of self-assessing would not affect their grades and encouraged them to try to accurately reflect on their learning.

\section{Results of Self-Assessment Checklist 2}

\section{Check Items}

Of the 82 students who completed Checklist 2, the majority self-rated each checklist item either 4 (to some extent) or 5 (very much). Figure 1 shows the compilation of the 4 and 5 ratings on items 1-11. Overall, both action (self-reactiveness) and reflection (self-reflectiveness) indicate high percentages, whereas thought (intentionality and forethought) shows high and low results depending on the check items. This tendency was shown equally in the four courses, although those in Course A showed slightly low ratings for all the checklist items except items 3 and 6 , which were related to worksheet completion and LP revisitations for quiz review respectively (see Figure 2).

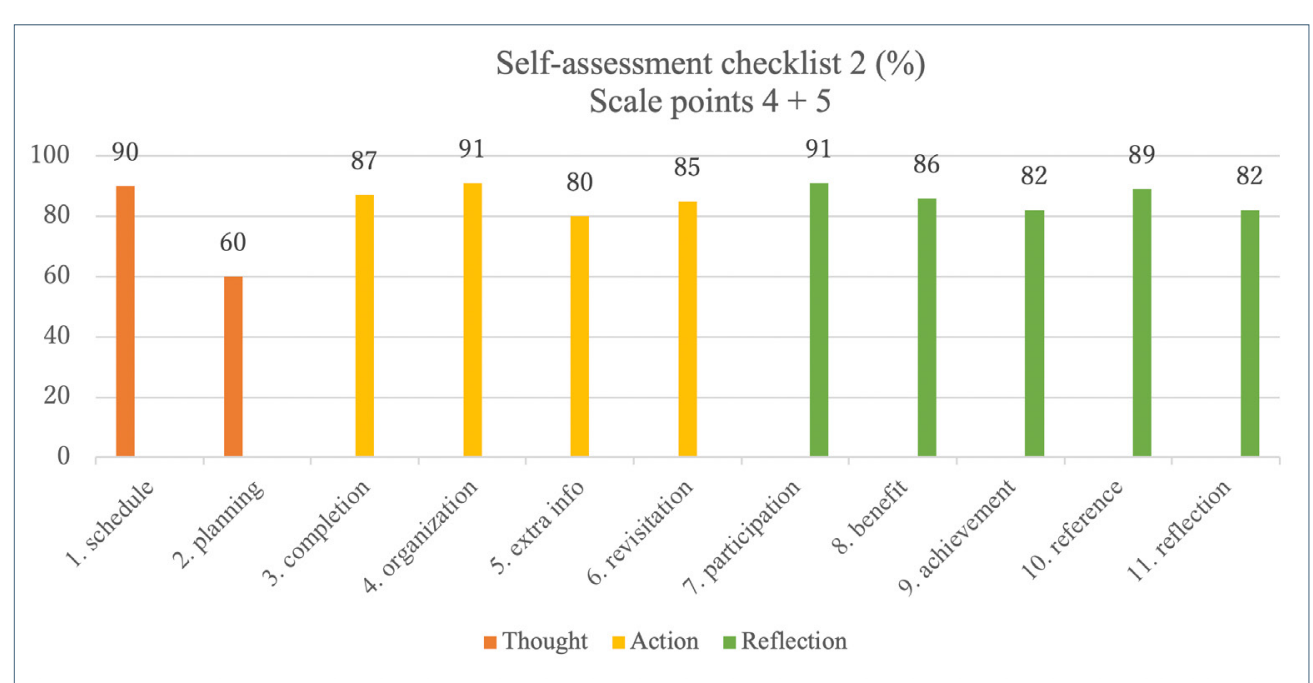

Figure 1. Self-assessed Bandura’s core features of human agency.

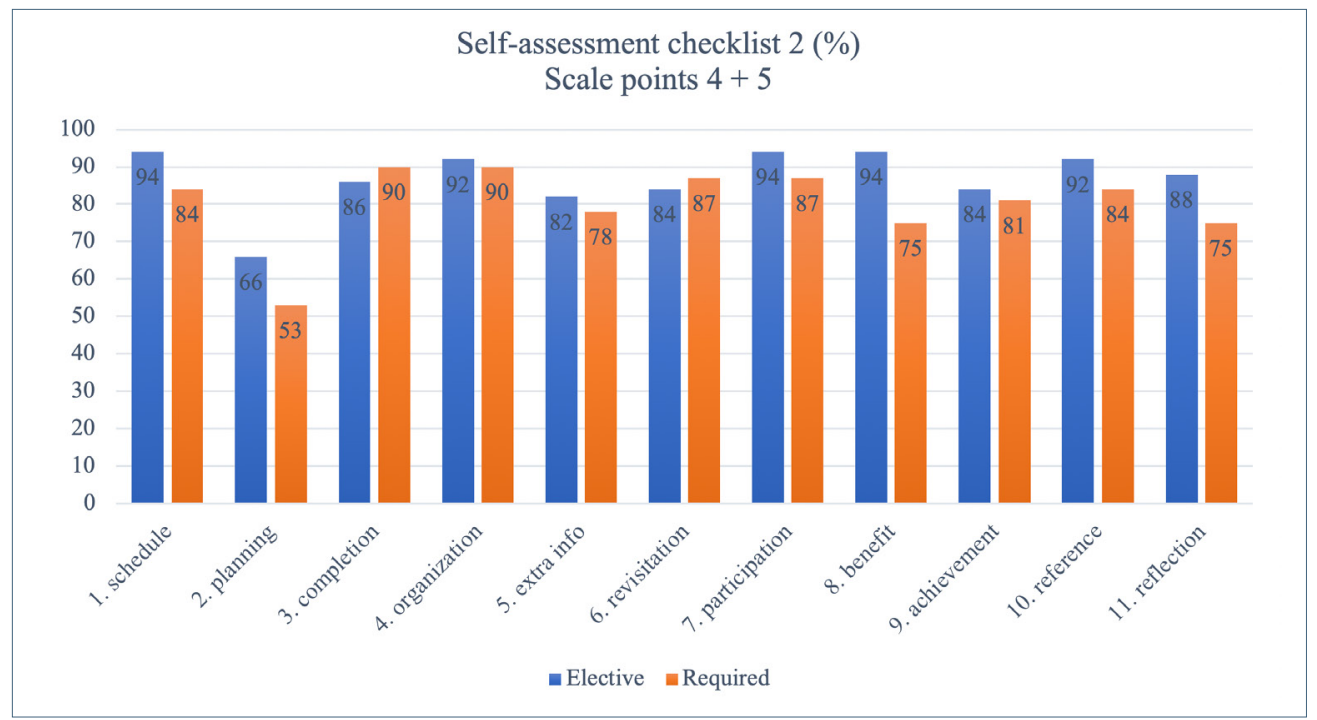

Figure 2. Self-assessment: students in elective courses vs. students in a required course. 


\section{LP Rating}

Regarding the LP evaluation (item 12), 60\% ( $n=50)$ gave a rating of 4 to their LPs, and a further $28 \%(n=23)$ selected 3 (satisfactory). When asked about the reasons for their ratings, two different trends were noted for students who responded with a 4 . Approximately half of them $(n=24)$ reported confidently that their LPs surpassed the middle rating (3) because they had completed and organized their worksheets and added extra information for their learning. The other half $(n=26)$ said their LPs fell short of the highest rating (5) because of inadequate worksheet completion and organization and adding less extra information. In either way, the decisive factors in their judgment on LP ratings were mainly the quality of worksheets and organization skills.

\section{Areas Improved After the Midterm Self-Assessment}

Figure 3 shows the areas in which the students tried to improve after the midterm self-assessment. Only five of the 82 students reported that they had not made any improvements for their learning in the latter half of the semester. The other 77 students reflected on their learning and made some improvements. Roughly a quarter of the students reported that they had improved the quality or efficacy of their LPs. Another quarter said that they had studied harder to improve the scores of their review quizzes. In addition, 13 students answered that they had self-studied outside the class more frequently than in the first half of the semester (see Figure 3).

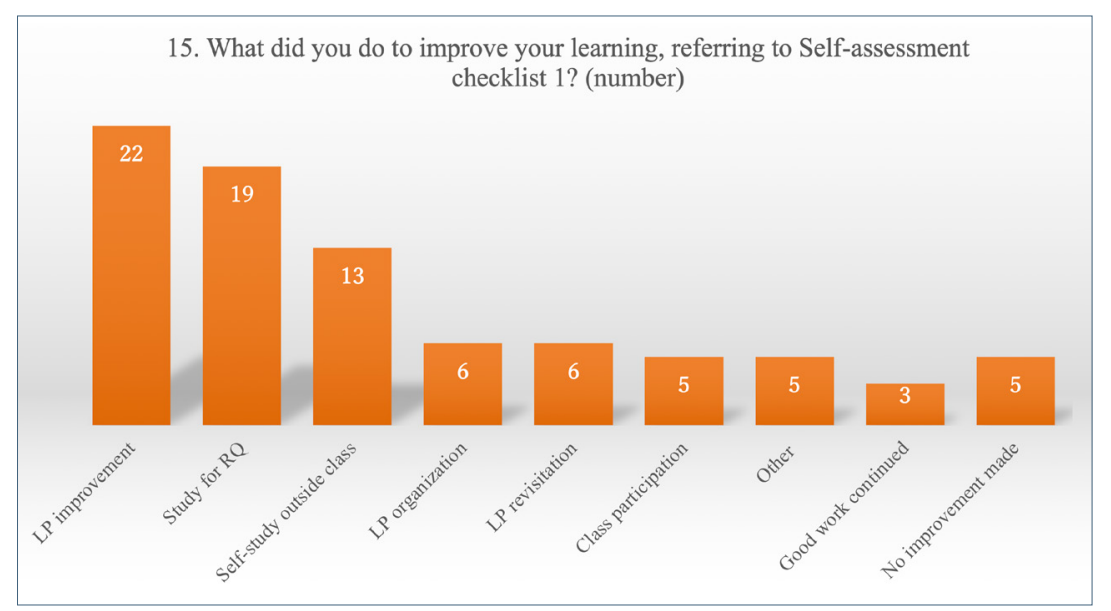

Figure 3. Student self-reports: areas improved after the midterm self-assessment.

\section{Goal Achievement}

For the latter half of the semester, all 82 students set at least one goal that was related to their EFL courses or their learning of English. When asked whether they had achieved their learning goals, $44 \%(n=37)$ answered in the affirmative, whereas $51 \%(n=43)$ responded negatively. Each of the two students who had set two goals reported that they had achieved one of their goals, but not the other. Therefore, these responses were calculated as both affirmative and negative responses. Four students said that they were unsure of whether they had achieved their goals or not at the time when they completed Checklist 2. When asked to justify their answers, four students, who had responded either affirmatively or negatively, did not give any reasons. Thirty students, especially those with negative responses, actually tried to justify the reasons for their judgments, but they were not able to fully explain.

\section{Discussion}

Through the results of Checklist 2, class observations, and LP inspections, I examined whether LPs helped the students to promote learner agency, in particular Bandura's (2001) core features of human agency: intentionality, forethought, self-reactiveness, and self-reflectiveness. I also re-evaluated the five documents I had created: the syllabus, preclass documents, the in-class document, the postclass document, and self-assessment checklists for their practicality.

\section{Intentionality}

If intentionality was interpreted as their intentions to complete their courses, it was clearly demonstrated in that none of the 82 students withdrew from class. In defining intentionality, Bandura $(2001$, p. 6) stated that "the power to originate actions for given purposes is the key feature of personal agency." In the midterm self-assessment, all of the students originated actions by setting learning goals for the latter half of the semester, which means they had intentions of trying to achieve those goals. Indeed, when commenting on progress on their goals in Checklist 2, none of them said that they had not established any goals. However short-term or easily achievable their goals were, it appeared that LPs played a certain role in promoting intentionality. 


\section{Forethought}

In contrast, LPs did not appear to promote students' forethought. Their responses to Item 2 in Checklist 2 indicate their lack of planning (see Figure 1). Bandura (2001, p. 7) pointed out "intentions center on plans of action," which implies that intentionality and forethought are closely intertwined. However, a certain number of students seemed to have acted without plans, or more precisely, they took action at the last minute. For instance, before taking review quizzes, the students usually had 10 minutes to look through their LPs once again as quiz preparation. However, some of them were probably opening their LPs for the first time since the previous class during that preparation time. This practice was particularly common among those students in Course A: many students confirmed with me just before the preparation time whether they would need to take review quizzes or what would be covered in quizzes, even though such information was all written in the syllabus (see 2. Planning in Figure 2).

Bandura (2001, p. 7) also posited that through forethought, people anticipate the consequences of future actions, sort out and generate courses of actions likely to produce preferred outcomes, and avoid adverse ones. It is questionable whether the students understood these processes of forethought or whether they made plans for class preparation and review with such heavy cognitive loads. Apparently, the syllabus that was designed to help students to make plans for their learning did not fully serve its purpose, even though almost all of them completed preclass and postclass documents.

\section{Self-Reactiveness}

Concerning self-reactiveness, the students well understood their requirements and duties, and most of them acted accordingly with the help of pre- and in-class documents that specified what the students were required to do. Apart from those course-content documents, Checklist 1 played a significant role in promoting their self-reactiveness. This checklist gave the students an opportunity to reflect on their learning performance in the first half of the semester and to shape their courses of action appropriately for the latter half of the semester. On Checklist 2, more than a quarter of the students reported that after completing Checklist 1, they had improved the quality or efficacy of their LPs by adding onto their daily worksheets useful information shared in class or their own comments on certain learning advice or strategies. In addition, some said that they had used coloured ink to identify their learning progress more clearly. Reactions were reported not only on their learning performance but also on their learning behaviour. Two students in Course A said that they had refrained from unnecessary use of smartphones in class. I often verbally warned the students on that course against inappropriate use of smartphones unrelated to class activities. However, as the situation did not improve as expected, I included a check item on this misbehaviour in Checklist 1. Such an attempt exemplifies how teachers can intervene to help promote students' selfreactiveness.

Feedback is another way of teachers intervening in students' learning. While examining their Checklist 1, I recalled learning performance and behaviour of each of the students. I gave feedback in writing, such as suggestions to improve learning performance in class; advice to reinforce the basic four skills; introduction of reference books, resources, and study strategies; and encouragement of out-of-class study, and then returned the assessment checklist to each student. Furthermore, during the midterm LP inspection, I identified good LP examples that had met requirements such as worksheet completion and organization and that had been customized with the adequate evidence of frequent revisitations and utilization by students. With the owners' consent, I shared such examples with the class, which should have contributed to promoting selfreactiveness because the students then actually understood what to do with their LPs.

\section{Self-Reflectiveness}

As for self-reflectiveness, the students seemed to have reflected well on their learning performance but not on their learning processes. Considering their LP ratings, most of the students evaluated their LPs on the basis of the quality of worksheets and organization skills, focusing on what they had done or what was in their LPs. Only a few students commented on how or how often they had used their LPs, which they said was the decisive factor in their judgment on LP rating. The same propensity applied to their comments on the justification for goal achievement. Thirty students, mainly with negative responses, gave the reasons for their failures or successes but were not able to adequately explain why. For example, a student said that his lack of concentration in class caused him to fail to achieve his goal. However, what I wanted him to reflect on was the reason why he had not concentrated or what had prevented him from concentrating. He may have lost interest in class content or may have been preoccupied with other subject matters or it was just because of a lack of sleep. Another example was a student writing "I did not make efforts to achieve my goal" but with no explanation as to why not. These unconstructive comments more often came from the students in the required course than those in the elective courses. In fact, half of the students in Course A made such comments on justification for goal achievement.

Self-reflectiveness is the metacognitive capability to reflect on actions and thoughts Learning performance will be easily reflected on if students keep tangible evidence 
of their actions, whereas learning processes are difficult to revisit because it may take more time and effort to reflect on each step throughout learning. Zimmerman (2008) discussed two key qualitative dimensions of self-regulation: proactive and reactive learning. Proactive learning helps learners to self-regulate more effectively because of active engagement in the forethought phase: task analysis and self-motivation. On the other hand, reactive learning is attributed to less effective self-regulation because learners count mostly on the self-reflection phase (self-judgments and self-reaction) to improve their performance (p. 279). The majority of the students in this study may have been reactive learners in that self-reactiveness and self-reflectiveness on actions appear to have been more noticeably identified than forethought. To convert reactive learners into proactive learners, Zimmerman (2008) proposed encouraging learners to set process goals for themselves, having learners envision themselves after attaining the goals they had set, and giving them rewards contingent to their performance. These suggestions are noteworthy for my further exploration of practical uses of LPs. Better ways along with better documents to promote students' forethought and self-reflectiveness on thoughts should be sought.

\section{Conclusion}

LPs have the potential to promote learner agency, but they are not a universal panacea. Their effectiveness may not be proven for every student or every teaching context. However, through the process of preparing, implementing, utilizing, and examining LPs in my teaching context, I reconfirmed advantageous aspects of LPs and discovered shortcomings of LPs that need to be remedied. Further attempts to develop students' forethoughts and self-reflectiveness through LPs should be made by creating class documents focusing not only on learning performance but also on learning processes. Through considering more efficient use of class time, more explicit instructions, and better ways to enhance student motivation for the creation and utilization of LPs, I will continue to explore the possibilities of LPs as a tool to promote learner agency.

\section{Bio Data}

Motoko Teraoka is a part-time university lecturer. Her interests include learner autonomy and self-regulated learning. <teraokamotoko@gmail.com>

\section{References}

Bandura, A. (2001). Social cognitive theory: An agentic perspective. Annual Reviews Psychology, 52, 1-26. Retrieved from https://www.uky.edu

Council of Europe (2019). European Language Portfolio (ELP): What is the ELP? Strasbourg, Cedex, France: Council of Europe. Retrieved from https://www.coe.int/portfolio

Esteve, O., Trenchs, M., Pujolà, J., Arumi. M., \& Birello, M. (2012). The ELP as a mediating tool for the development of self-regulation in foreign language learning university contexts: An ethnographic study. In B. Kühn \& M. L. P. Cavana (Eds.), Perspectives from the European language portfolio: Learner autonomy and self-assessment (pp. 73-99). Oxon, England: Routledge.

Horiuchi, S., Harada, Y., Imoto, Y., \& Atobe, S. (2010). The implementation of a Japanese version of the "European language portfolio - junior version - " at Keio: Implications from the perspective of organizational and educational anthropology. In M. G. Schmidt, N. Naganuma, F. O'Dwyer, A. Imig, \& K. Sakai (Eds.), Can do statements in language education in Japan and beyond: Applications of the CEFR (pp. 138-154). Tokyo: Asahi Press.

Kohonen, V. (2012). Developing autonomy through EFP-oriented pedagogy: Exploring the interplay of shallow and deep structures in a major change within language education. In B. Kühn \& M. L. P. Cavana (Eds.), Perspectives from the European language portfolio: Learner autonomy and self-assessment (pp. 22-42). Oxon, England: Routledge.

Kühn, B., \& Cavana, M. L. P. (2012). Introduction. In B. Kühn \& M. L. P. Cavana (Eds.), Perspectives from the European language portfolio: Learner autonomy and self-assessment (pp. 7-21). Oxon, England: Routledge.

Little, D. (2012). The European language portfolio: History, key concerns, further prospects. In B. Kühn \& M. L. P. Cavana (Eds.), Perspectives from the European language portfolio: Learner autonomy and self-assessment (pp. 7-21). Oxon, England: Routledge.

Martyniuk, W. (2012). The European language portfolio (ELP) in its original Council of Europe context. In B. Kühn \& M. L. P. Cavana (Eds.), Perspectives from the European language portfolio: Learner autonomy and self-assessment (pp. 59-70). Oxon, England: Routledge.

Reeve, J., Ryan, R., Deci, E. L., \& Jang, H. (2008). Understanding and promoting autonomous selfregulation: A self-determination theory perspective. In D. H. Schunk \& B. J. Zimmerman (Eds.), Motivation and self-regulated learning: Theory, research, and applications (pp. 223-244). New York, NY: Routledge.

Sato, Y. (2010). Using can do statements to promote reflective learning. In M. G. Schmidt, N. Naganuma, F. O'Dwyer, A. Imig, \& K. Sakai (Eds.), Can do statements in language education in Japan and beyond: Applications of the CEFR (pp. 184-199). Tokyo: Asahi Press.

Teraoka, M. (2015). The role of a language portfolio for Japanese university students in TOEIC preparatory classes: The applicability of an LP for the acquisition of strategies and skills. Studies in English Language Teaching, 38, 45-54. 
Teraoka, M. (2016). Class narratives through a language portfolio. In G. Brooks, M. Porter, D.

Fujimoto, \& D. Tatsuki (Eds.), The 2015 PanSIG Journal (pp. 191-197). Tokyo: JALT.

Zimmerman, B. J. (2008). Goal setting: A key proactive source of academic self-regulation. In D.

H. Schunk \& B. J. Zimmerman (Eds.), Motivation and self-regulated learning: Theory, research, and applications (pp. 267-295). New York, NY: Routledge.

\section{Appendix}

Self-Assessment Checklist 2

Twelve items to rate 1 to 5:

Thought

1. I understood the course schedule, requirements, and grading criteria written on the syllabus.

2. I made plans for class preparation and review, referring to the syllabus.

Action

3. I brought my portfolio to every class and complete daily worksheets.

4. I organized my worksheets and handouts in my portfolio.

5. I added extra information to my worksheets to make my portfolio more efficient.

6. I revisited my textbook and portfolio to study for review quizzes.

Reflection

7. I participated actively in class work by creating my portfolio.

8. My portfolio benefited my learning.

9. The creation of my portfolio gave me a sense of achievement.

10. My portfolio is a good reference for self-study.

11. I reflected on my learning processes through my portfolio.

12. Rate your portfolio on a 1 (poor) to 5 (excellent).

\section{Four items to write about:}

1. Give the reasons for your portfolio rating.

2. How do you feel your portfolio contributed to your learning?

3. What did you do to improve your learning referring to Self-assessment Checklist 1?

4. Did you achieve your goal for this semester? Justify. 